\title{
Credit Rationing with Heterogeneous Borrowers in Transition Economies: Evidence from Slovakia
}

\author{
Pavel Ciaian
}

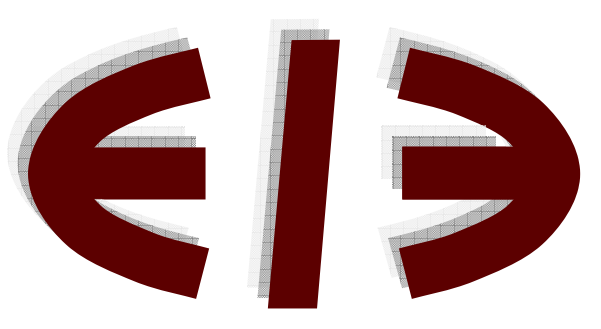

EERI

Economics and Econometrics Research Institute Avenue de Beaulieu

1160 Brussels

Belgium

Tel: +322 2993523

Fax: +322 2993523

www.eeri.eu 


\title{
Credit Rationing with Heterogeneous Borrowers in Transition Economies: Evidence from Slovakia
}

\author{
Pavel Ciaian \\ Katholieke Universiteit Leuven and \\ EERI Economics and Econometrics Research Institute \\ e-mail:pavel.ciaian@econ.kuleuven.be
}

\begin{abstract}
This paper investigates the macroeconomic importance of credit rationing and whether banks use characteristics such as ownership structure and institutional type of borrowers in order to regulate the risk of loaned funds. To test this, monthly data for 2000-2002, extracted from the National Bank of Slovakia monetary review, were used. The paper finds that credit rationing was not present during the period analysed, implying that the credit market can be approximated with a typical supply and demand relationship. The second finding of the paper is that intermediaries use the ownership type and institutional form of borrowers to regulate risk.
\end{abstract}

Key words: credit rationing, heterogeneous borrowers,

JEL Classification: E51, G32, P24 


\title{
Credit Rationing with Heterogeneous Borrowers in Transition
}

\author{
Economies: Evidence from Slovakia
}

\author{
Pavel Ciaian
}

\section{Introduction}

Access to credit is an important factor that determines the investment behaviour of firms and thus the performance of the real economy. This is even more pronounced in transition countries, given the fact that their economies need to be restructured and modernised. Some firms, or borrowers, may be rationed and not get full access to credit, even though they may be willing to pay a higher interest rate than the one charged by intermediaries. Thus the typical law of supply and demand may not hold, meaning that the credit market does not clear at the rate where demand equals supply. Stiglitz \& Weiss (1981) have shown that, owing to asymmetric information, banks may not be willing to offer a loan to all applicants. Some of the applicants may be rationed because of adverse selection. With an increase in the loan rate, banks' profits may decline because the pool of applicants that apply for loans worsens. In this situation only riskier applicants are able to obtain positive expected profits, thus only they apply for loans. By charging a lower loan rate, a bank's profits may increase because it attracts less risky borrowers. An equilibrium situation may therefore arise where the intermediaries charge a lower loan rate than the market clearing rate.

An important assumption behind this result is that intermediaries cannot distinguish between different types of borrowers. In reality this may not always be the case. For instance, characteristics of a loan applicant that are almost costlessly observed are ownership (state versus private) and institutional form (profit versus non-profit). Different groups of borrowers might be associated with different levels of risk, with different levels of average profits, and 
thus can be offered different contracts. This means that the loan rate charged by intermediaries will differ among the distinguishable groups. The most profitable groups, from the bank's perspective, will be offered a loan first, and rationed credit might ultimately be offered to one group only, the least profitable one. Riley (1987) has shown that when there is a large number of borrowers' groups, the macroeconomic importance of credit rationing declines and might be unimportant empirically. Rather the typical supply and demand relationship should hold.

In this paper data from the National Bank of Slovakia (NBS) are used first to test the macroeconomic importance of the Stiglitz \& Weiss (1981) credit rationing versus Riley’s (1987) no credit rationing, and second to test whether characteristics such as ownership structure and institutional type of borrowers are used by intermediaries to regulate risk.

The paper is organised as follows. The next two sections discuss how risk is related to ownership and institutional type of borrowers respectively. We then describe the data used and discuss the estimating framework and the results. The final section concludes.

\section{Risk and Ownership}

Ownership type alters incentives within a firm and thus it affects the firm's overall performance. Private owned firms unlike state owned ones, are expected to perform activities more efficient since the owners are residual claimants and therefore they have incentive to obtain maximum revenues with minimum costs. Consequently it is expected that activities undertaken by private firm are expected to yield a larger expected return as compared to returns earned from the same activities if undertaken by state firms.

When borrowing, private firms put at stake their assets either as collateral or in the case that they default, the lender seizes their assets. By contrast, state firms use state assets 
and there is not a direct individual that would bear the losses of potential default. The effect of this is that state firms might be involved in riskier activities as compared to private ones.

Private firms, being more profitable and being involved in less riskier activities, are therefore expected to be categorised by intermediaries as a group of borrowers with better credit worthiness. However, state always can intervene to support its firms when they have financial difficulties and thus this may offset the disadvantage that state firms have toward banks due to being less efficient and riskier. This practice was widely spread in former communist countries. Public or state firms used to operate under soft budget constraint during the Communism (Kornai, 1980). Politically, default was not acceptable and it was usually avoided thorough wide range of financial aid provided by the state. This aid was usually in the from of loan guarantees, subsidies and price support. To a large extent, the state continued with this practice after the fall of Communism (Tajnikar, 2001; Lizal \& Svejnar, 2002; Konings et al. 2003). Loan guaranties and subsidies granted to the state sector were relatively common in the new economic and political environment introduced at the beginning of the 90s.

In summary, there are two opposite factors that affect credit worthiness of private versus state owned borrowers. Firstly, because of enhanced incentives and involvement in less riskier activities, private borrowers are expected to be preferred by intermediaries and offered a lower loan rate in order to avoid adverse selection. State firms being riskier are offered a higher loan rate because the bank's maximum profit reaches the peak at a higher rate. Secondly, this disadvantage of state firms may be offset by state interventions. If the government is active in supporting state firms, lending to them becomes less risky and thus it might be observed that intermediaries offer them a lower loan rate. 


\section{Risk and Institutional Type of Borrowers}

Organisations that apply for a loan can be of different institutional type. Two important categories are of a particular importance: profit driven and non-profit driven organisations. The motives of running a profit organisation are usually to make profits and distribute it to its owners. On the other hand, non-profit organisations perform activities in order to fulfil other then financial needs to its founders. This differences in motives between the two institutional types affects incentives within them in disfavour of non-profit organisations. Moreover, nonprofit companies are usually involved in activities that are commercially less profitable, with low returns and therefore more risky. As a result, intermediaries are expected to provide a better contract to profit organisation as compared to non-profit.

\section{Data}

Monthly data for period 2000 - 2002, extracted from the National Bank of Slovakia monetary review, were used. Among others, the data include macroeconomic indicators and loan rates charged by intermediaries for borrowers categorised by ownership and institutional type. Summary statistics are shown in tables 1 and 2. Table 1 gives selected macroeconomic variables. Table 2 provides average yearly loan rates categorised by borrower type.

GDP growth, inflation and foreign reserves show an improvement while trade balance, foreign debts and budget deficit have worsened over the period 2000-2001. Concerning unemployment, it remained relatively unchanged over this period. From Table 2 it can be noted that foreign private firms and households obtained credits with the lowest loan rate. They were followed by state firms, domestic private firms and public administration. The last in this ranking are non-profit organisations. They were charged the highest loan rate. 


\section{The Estimating Framework}

In order to test macroeconomic importance of credit rationing and whether the characteristics such as ownership structure and institutional type of borrowers are used by the intermediaries to regulate risk, the following model is estimated:

LOANR $_{\mathrm{it}}=\mathrm{C}+\alpha *$ DEPOSITR $_{\mathrm{t}-1}+\beta *$ DEPOSIT $_{\mathrm{t}-3}+\delta * \mathrm{M}(2)_{\mathrm{t}}+\varepsilon^{*} \mathrm{INF}_{\mathrm{t}-1}+\phi * \mathrm{NETDEBT}_{\mathrm{t}-2}+$ $\gamma * \mathrm{TRADE}_{\mathrm{t}}+\varphi^{*} \mathrm{G}_{\mathrm{t}}+\kappa^{*} \mathrm{TREND}+\eta_{1} * \mathrm{DOM} \_\mathrm{PR} \_\mathrm{F}_{\mathrm{it}}+\eta_{2} * \mathrm{FOR} \_\mathrm{PR} \_\mathrm{F}_{\mathrm{it}}+\eta_{3} * \mathrm{PUBLICAD}_{\mathrm{it}}+$ $\eta_{4} * \mathrm{HOUSH}_{\mathrm{it}}+\eta_{5} *$ NOPR_O $\mathrm{it}+\eta_{6} * \mathrm{OTHER}_{\mathrm{it}}+\mu * \mathrm{LOANR}_{\mathrm{it}-1}+w_{i t}$

where $\mathrm{C}$ is a constant, $\mathrm{LOANR}_{\mathrm{it}}$ is average monthly loan rate that intermediaries charge borrower type $i^{1}$ at period $t$, DEPOSITR is average monthly deposit rate earned by deposit holders, DEPOSIT are total deposits and proxies for the supply of money that intermediaries can use as loanable funds, $M(2)$ is $M(2)$ money and it reflects the stance of the monetary policy of the Central Bank, NETDEBT are Slovak foreign debts minus foreign currency reserves, TRADE is trade balance, G is budget deficit, TREND is time variable and $w_{i t}$ is error term assumed to be independent with normal distribution and with mean zero. Seven type of borrowers are distinguished: state firms, domestic private firms (DOM_PR_F), foreign private firms (FOR_PR_F), public administration (PUBLICAD), households (HOUSH), non-profit organisations (NOPR_O ) and other borrowers (OTHER). For all of them a dummy variable was introduced. The dummy variable takes value 1 if the observation is for type $i$ otherwise it takes value 0 . To avoid perfect multicollinearity the dummy variable for state firms was excluded from the model. As a result, all the estimated coefficients $\eta_{1} \ldots \eta_{6}$ will represent the relative difference in the loan rate between what state farms and a respective type of borrower are charged by intermediaries. 
Following Riley's (1987) suggestion, coefficients $\beta$, which stands for the total deposits supplied to the bank sector, will be used to test for the presence of credit rationing. If the coefficient is statistically not significant, then credit rationing is present. An insignificant coefficient implies that the loan rate charged by intermediaries is not affected by the change in the total supply of loanable funds. Thus there must be a significant amount of rationed borrowers who are willing to pay a higher loan rate than the one charged by intermediaries. If the coefficient is negative and significant then credit rationing is unimportant at macroeconomic level, rather a typical supply-demand relationship holds. The more loanable funds are available the lower the loan rate is.

The coefficients corresponding to borrower type $\eta_{1} \ldots \eta_{6}$ will be used to test whether intermediaries are using borrowers' characteristics (ownership and institutional type) to regulate risk of the loaned funds. If the coefficients are statistically significant then intermediaries are indeed using borrowers' characteristics to regulate risk. In this case each type of borrower will be offered a different loan rate. This is because, as explained above, the types differ in their riskyness and in the expected return that they earn from the performed activities. When a bank increases the loan rate for type $i$ then there are two opposing effects which affect the bank's return earned from borrowers of type $i$. The first is a direct effect which is transmitted through the change of the bank's return per each Slovak crown loaned. When the bank increases the loan rate, the return per each crown loaned increases proportionally with the change in loan rate. The second effect is indirect, via worsening the pool of borrowers that apply for loans. Only more risky borrowers apply for a loan when the bank increases the loan rate, and consequently as more of them default the bank's return declines. Therefore, there must be an optimal loan rate, for each type different, at which the bank's returns reach maximum per each crown invested. If the loan rate charged is below this optimal rate, then the first effect dominates the second, while at a rate above the optimal loan 
rate, the second effect dominates the first. Assuming perfect competition in the banking sector, the equilibrium arises where for each group of borrowers, banks earn the same return per crown invested and also banks earn zero profit (Stiglitz \& Weiss, 1981). From this immediately follows, that in order the bank to earn from each group the same return per crown loaned, it must charge each group a different loan rate. When assuming that all the categories of borrowers earn the same expected return for a given activity, a higher loan rate will be associated with more riskier borrowers. However if the coefficients $\eta_{1} \ldots \eta_{6}$ are statistically not significant then banks are not using ownership and institutional characteristics of borrowers to regulate risk and they charge the same rate each type.

\section{Empirical Estimates}

The regression results are reported in Table 3. In the first column estimated results using simple OLS are shown. The White heteroskedasticity test, shown at the bottom of the table 3, indicates the presence of heteroskedasticity, meaning that the variance of the error term varies over the observations. One would expect that the variance for the high-loan rate borrowers is higher than the variance for the low-loan rate borrowers. As a result, White standard errors are used instead of the standard OLS errors.

To account for the presence of heteroskedasticity, weighted OLS is also estimated. The results are reported in the second column of table 3 . The White test indicates that the heteroskedasticity was removed.

The estimated $\beta$ coefficients, corresponding to the variable total deposits supplied to intermediaries (DEPOSIT), are negative and significant for the weighted OLS. This result implies that credit rationing was not present in Slovakia during the analysed period 20002002. Rather, the credit market operated through classical Walrasian mechanism, where market clears at the rate where supply equals demand. This finding has an important 
implication for monetary policy. Namely that the monetary policy is transmitted to real economy through interest rate channel rather than through credit rationing channel as suggested by Blinder \& Stiglitz (1983) and Blinder (1987).

The coefficients $\eta_{1} \ldots \eta_{6}$ standing for borrower type, DOM_PR_F, FOR_PR_F, PUBLICAD, HOUSH, NOPR_O, OTHER, are highly significant for all two models. The only exemption is the coefficient corresponding to the other borrowers group. This implies that intermediaries are using borrowers' characteristics (ownership and institutional type) to regulate the risk of the loaned funds. Each category of borrower is offered a different loan rate. The values of the coefficients represent the relative difference in the loan rate with respect to state firms. A negative value of the coefficient for a respective group implies that the group was charged a lower loan rate than the state firms, while a positive value implies the opposite.

According to the expectation, intermediaries charged domestic private firms (DOM_PR_F) a higher loan rate than the state firms. Thus the state firms disadvantage of being less efficient and involved in riskier activities is offset by the government's provision of aid in times of financial distress. On the other hand, this does not hold if compared with foreign private firms (FOR_PR_F). They received loans with a lower rate than the state firms. Foreign owned firms might be associated with better entrepreneurial capabilities and most importantly they might be financially backed by their parent company. Thus this enhances their credit worthiness as compared to state firms and domestic private firms. Regarding nonprofit organisations (NOPR_O), as expected, they were charged the highest loan rate, reflecting their low efficiency and high level of risk when lending to them.

The signs of the coefficients for the variables public administration (PUBLICAD) and households (HOUSH) are rather unexpected. Public administration obtained more expensive loans while household obtained cheaper loans then the state firms. Public administration 
includes mostly local governments and households include private individuals. One would expect that borrowing to the public sector is associated with low risk and therefore it would be offered a lower rate than the state firms, while the opposite is valid for households. An explanation is that government provides subsidies for mortgage loans acquired by households, which significantly decreases the rate that they have to pay.

The majority of the coefficients for the remaining variables are statistically significant for the weighted OLS. The variable G, standing for the state budget deficit, and variable TRADE, standing for trade balance are the only two that are significant for both models. The sign for $G$ is negative according to the expectation, implying that when government borrowing increases (when the budget deficit is larger), the loan rates charged by intermediaries increase for all categories of borrowers. What concerns the coefficient of TRADE variable, its sign is positive. A lower trade deficit might be as a result of an increase of domestic or foreign demand for domestic goods, which has a positive effect on economic activity. This in return increases the financial_needs of the companies and therefore it has an upward pressure on interest rate._Regarding the coefficient corresponding to deposit rate, it is significant (DEPOSITR) for the weighted OLS model. This is expected result, confirming Riley's (1987) finding that the loan rate for each category increases with the equilibrium cost of loanable funds. The sign of the coefficient standing for the variable inflation (INF) is also in accordance with expectation, positive, but again significant only when estimated by the weighted OLS. Finally, the variable reflecting the stance of the monetary policy of the Central Bank, $\mathrm{M}(2)$, is significant at $10 \%$ for weighted OLS model and has expected sign. This result shows that a decline in stock of money (restrictive monetary policy) leads to an increase of the interest rate charged by intermediaries. 


\section{Conclusions}

This paper has used monthly data extracted from the National Bank of Slovakia monetary review to test for macroeconomic importance of credit rationing and to test whether the characteristics such as ownership structure and institutional type of borrowers are used by the intermediaries to regulate risk.

The paper find that credit rationing was not present in Slovakia during the analysed period, implying that Slovak credit market can be approximated with typical supply and demand relationship where market clears at the rate where supply equals demand. This however has an important implication for monetary policy. Namely that the monetary policy is transmitted to real economy through interest rate channel rather than through credit rationing channel as suggested by Blinder \& Stiglitz (1983) and Blinder (1987).

Other important finding of the paper is that intermediaries are using borrowers' characteristics, such as their ownership structure and institutional form, to regulate for the risk. Different categories are offered a different loan rate. Non-profit organisations obtain the most expensive loans while foreign private firms and households obtain the cheapest loans. The results also imply that the government still provides a significant amount of financial aid to state firms so that lending to them is less risky as compared to lending to domestic private firms even though they are more efficient.

\section{Notes}

1. For $i=$ state firms, domestic private firms, foreign private firms, public administration, households, non-profit organisations and other borrowers. 


\section{References}

1. Stiglitz, J.E. \& Weiss, A., 'Credit rationing in markets with imperfect information', American Economic Review, 71, 3, 1981, pp. 393-410.

2. Riley, J.G., 'Credit rationing: A further remark', American Economic Review, 77, 1, 1987, pp. 224-227.

3. Kornai, J., Economics of shortage, (North Holland, Amsterdam, 1980).

4. Tajnikar, M., 'Transitional adjustment of large companies in Slovenia and economic policy', Post-Communist Economies, 13, 3, 2001, pp. 331-344.

5. Lizal, L., \& Svejnar, J., 'Investment, credit rationing and the soft budget constraint: Evidence from Czech panel data', Review of Economics and Statistics, 84, 2, 2002, pp. 353370.

6. Konings, J., Rizov, M. \& Vandenbussche, H., 'Investment and financial constraints in transition economies: micro evidence from Poland, the Czech Republic, Bulgaria and Romania', Economics Letters, 78, 2, 2003, pp. 253-258.

7. Blinder, A.S. \& Stiglitz, J.E., 'Money, credit constraints, and economic activity', American Economic Review, 73, 2, 1983, pp. 297-302.

8. Blinder, A.S., 'Credit rationing and effective supply failures', Economic Journal, 97, 386, 1987, pp. 327-352. 
Tables

Table 1. Main macroeconomic indicators

\begin{tabular}{llll}
\hline & 2000 & 2001 & 2002 \\
\hline GDP growth (\%) & 1.7 & 3.1 & 4.1 \\
Unemployment (\%) & 16.7 & 18.3 & 17.8 \\
Inflation (\%) & 12.2 & 7.3 & 3.4 \\
Trade balance (\% of GDP) & -4.7 & -10.4 & \\
Budget deficit (\% of GDP) & -3.1 & -4.5 & \\
Foreign reserves (bn. USD) & 5.1 & 5.3 & 8.1 \\
Foreign debts (bn. USD) & 10.7 & 10.9 & 11.9 \\
\hline
\end{tabular}

Source: National Bank of Slovakia and Slovak Statistical Office

Table 2. Average yearly loan rates by borrower type (\%)

\begin{tabular}{llll}
\hline & 2000 & 2001 & 2002 \\
\hline State firms & 11.8 & 9.6 & 9.8 \\
Domestic private firms & 14.7 & 11.2 & 10.2 \\
Foreign private firms & 10.0 & 8.4 & 8.1 \\
Public administration & 16.0 & 11.4 & 10.0 \\
Households & 8.5 & 8.8 & 10.1 \\
Non-profit organisations & 20.2 & 16.8 & 13.6 \\
Other & 11.4 & 9.2 & 10.9 \\
\hline
\end{tabular}

Source: National Bank of Slovakia 
Table 3. Dependent Variable: $\log \left(\mathrm{LOANR}_{\mathrm{it}}\right)$

\begin{tabular}{|c|c|c|}
\hline & $\begin{array}{c}\text { OLS } \\
\text { withWhite standard errors } \\
\text { (1) }\end{array}$ & $\begin{array}{c}\text { Weighted OLS } \\
\text { (2) }\end{array}$ \\
\hline CONSTANT & $\begin{array}{l}10.694 \\
(6.953)\end{array}$ & $\begin{array}{l}13.720 * * * \\
\quad(4.481)\end{array}$ \\
\hline $\log \left(\mathrm{DEPOSITR}_{\mathrm{t}-1}\right)$ & $\begin{array}{l}0.071 \\
(0.088)\end{array}$ & $\begin{array}{l}0.117^{*} \\
(0.063)\end{array}$ \\
\hline $\log \left(\mathrm{DEPOSIT}_{\mathrm{t}-3}\right)$ & $\begin{array}{l}-0.391 \\
(0.709)\end{array}$ & $\begin{array}{c}-1.081 * * * \\
(0.401)\end{array}$ \\
\hline $\log \left(\mathrm{M}(2)_{\mathrm{t}}\right)$ & $\begin{array}{l}-1.011 \\
(0.676)\end{array}$ & $\begin{array}{c}-0.832 * \\
(0.430)\end{array}$ \\
\hline $\mathrm{INF}_{\mathrm{t}-1}$ & $\begin{array}{l}0.018 \\
(0.016)\end{array}$ & $\begin{array}{l}0.015^{*} \\
(0.008)\end{array}$ \\
\hline $\log \left(\mathrm{NETDEBT}_{\mathrm{t}-2}\right)$ & $\begin{array}{l}0.038 \\
(0.061)\end{array}$ & $\begin{array}{c}0.048 \\
(0.040)\end{array}$ \\
\hline $\mathrm{TRADE}_{\mathrm{t}}$ & $\begin{array}{c}0.003 * * * \\
(0.001)\end{array}$ & $\begin{array}{l}0.001^{*} \\
(0.000)\end{array}$ \\
\hline $\mathrm{G}_{\mathrm{t}}$ & $\begin{array}{c}-0.006 * * * \\
(0.002)\end{array}$ & $\begin{array}{c}-0.003^{* *} \\
(0.001)\end{array}$ \\
\hline TREND & $\begin{array}{l}0.004 \\
(0.008)\end{array}$ & $\begin{array}{l}0.007 \\
(0.005)\end{array}$ \\
\hline DOM_PR_F $F_{\text {it }}$ & $\begin{array}{c}0.137 * * * \\
(0.021)\end{array}$ & $\begin{array}{c}0.123 * * * \\
(0.017)\end{array}$ \\
\hline FOR_PR_F $F_{i t}$ & $\begin{array}{l}-0.160 * * * \\
\quad(0.018)\end{array}$ & $\begin{array}{l}-0.164 * * * \\
\quad(0.016)\end{array}$ \\
\hline PUBLICAD $_{\text {it }}$ & $\begin{array}{c}0.159 * * * \\
(0.028)\end{array}$ & $\begin{array}{c}0.139 * * * \\
(0.023)\end{array}$ \\
\hline $\mathrm{HOUSH}_{\mathrm{it}}$ & $\begin{array}{c}-0.124^{* * *} \\
(0.036)\end{array}$ & $\begin{array}{c}-0.107 * * * \\
(0.031)\end{array}$ \\
\hline NOPR_O & $\begin{array}{c}0.459 * * * \\
(0.038)\end{array}$ & $\begin{array}{c}0.447 * * * \\
(0.030)\end{array}$ \\
\hline OTHER $_{\text {it }}$ & $\begin{array}{l}-0.004 \\
(0.037)\end{array}$ & $\begin{array}{l}-0.050 \\
(0.032)\end{array}$ \\
\hline $\log \left(\mathrm{LOANR}_{\mathrm{it}-1}\right)$ & $\begin{array}{l}0.102 \\
(0.156)\end{array}$ & $\begin{array}{l}0.080 \\
(0.079)\end{array}$ \\
\hline Adjusted R-squared & 0.677 & 0.997 \\
\hline $\begin{array}{l}\text { RESET test (p-values) } \\
\text { FITTED^2 } \\
\text { FITTED^3 }\end{array}$ & $\begin{array}{l}0.0001 \\
0.0002\end{array}$ & $\begin{array}{l}0.273 \\
0.410\end{array}$ \\
\hline $\begin{array}{l}\text { White Heterosked. test } \\
\text { - No cross terms } \\
\text { - Cross terms }\end{array}$ & 0.0006 & $\begin{array}{l}0.384 \\
0.233 \\
\end{array}$ \\
\hline
\end{tabular}

Standard errors in parenthesis.

$* * *=$ significant at $1 \%$ level

$* *$ = significant at $5 \%$ level

$*=$ significant at $10 \%$ level

In the last four rows p-values for RESET tests and White Heteroskedasticity test are provided. A value lower than 0.05 for RESET test would suggest that the model is misspecified at $5 \%$ significance level. A value lower than 0.05 for White Heteroskedasticity test would suggest the presence of heteroskedasticity at $5 \%$ significance level. 